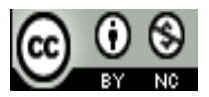

Jurnal Pendidikan Dasar Indonesia is licensed under

A Creative Commons Attribution-Non Commercial 4.0 International License

\title{
EFEKTIVITAS MODEL PEMBELAJARAN IPA MITIGASI BENCANA TERHADAP HASIL BELAJAR SISWA SEKOLAH DASAR
}

\author{
Nelly Wedyawati ${ }^{1)}$, Yasinta Lisa ${ }^{2)}$, Erma Ester Magdovia ${ }^{3)}$ \\ ${ }^{1), 2)}$ PGSD STKIP Persada Khatulistiwa Sintang, Kalimantan Barat \\ E-mail: nellywedyawati@ymail.com \\ ${ }^{2)}$ Pendidikan Biologi STKIP Persada Khatulistiwa Sintang, Kalimantan Barat \\ E-mail: yasintalisa@gmail.com
}

\begin{abstract}
Abstrak: Tujuan penelitian adalah untuk mengetahui efektivitas model pembelajaran IPA mitigasi bencana terhadap hasil belajar siswa. Pendekatan penelitian yang digunakan adalah pendekatan kuantitatif dengan metode eksperimen. Bentuk penelitian ini adalah bentuk quasi eksperimen design dengan bentuk desain nonequivalent control group design. Populasi dalam penelitian ini adalah seluruh siswa kelas IV SD Negeri 09 Sintang dengan sampel penelitian 24 siswa di kelas IV A sebagai kelas eksperimen dan 25 siswa di kelas IV B sebagai kelas kontrol. Teknik dan alat pengumpulan data menggunakan observasi langsung, pengukuran, komunikasi tidak langsung dan dokumentasi. Perhitungan efektivitas menggunakan rumus effect size. Hasil perhitungan menunjukan bahwa: (1) Hasil pretest kelas eksperimen sebesar 36,75 sedangkan hasil posttest sebesar 80,75 dengan peningkatan sebesar 0,69 sedangkan pada kelas kontrol hasil pretest sebesar 38,4 dan hasil posttest sebesar 70,6 dengan peningkatan sebesar 0,52 (2) Hasil pengujian hipotesis pretest kelas eksperimen dan kelas kontrol diperoleh $-0,495<2,02835$ Ho diterima dan Ha ditolak. Hasil pengujian pada posttest kelas eksperimen dan kelas kontrol diperoleh 3,94 $\geq 2,02835$ Ho ditolak dan Ha diterima. (3) Hasil perhitungan effect size sebesar 1,66 dengan kategori tinggi. Berdasarkan simpulan hasil penelitian menunjukan model pembelajaran IPA Mitigasi Bencana pada siswa efektif dan meningkatkan hasil belajar.
\end{abstract}

Kata Kunci: Efektivitas Model Pembelajaran IPA, Mitigasi Bencana, Hasil Belajar.

\section{Pendahuluan}

Mempelajari semua ilmu pengetahuan sangat penting bagi peserta didik guna sebagai bekal untuk menjalani kehidupan di masa depan. Ilmu pengetahuan diantaranya yaitu ilmu pengetahuan umum, Ilmu Pengetahuan Sosial dan Ilmu Pengetahuan Alam. Salah satu ilmu pengetahuan yang penting untuk dipelajari yaitu Ilmu Pengetahuan Alam. Menurut Sugiantari dkk (2013) "IPA di sekolah dasar merupakan program untuk menanamkan dan mengembangkan pengetahuan, keterampilan, sikap, dan nilai ilmiah pada siswa. Tujuan IPA secara umum adalah membantu agar siswa memahami konsep IPA dan keterkaitannya dengan kehidupan sehari-hari". Mempelajari ilmu pengetahuan alam berguna agar bisa mengetahui segala hal mengenai lingkungan hidup yang berhubungan dengan alam.

Masalah lingkungan yang sudah sering kali kiita jumpai disekitar kita, baik secara global maupun secara lokal. Bencana merupakan salah satu masalah lingkungan. Chandra dan Supriharjo (2013: 25), mengungkapkan bahwa "Bencana merupakan suatu peristiwa di alam yang disebabkan oleh manusia maupun alam yang berpotensi merugikan kehidupan manusia". Bencana yang disebabkan oleh aktivitas manusia yaitu kekeringan, banjir, tanah longsor dan kebakaran hutan.

Menurut data wawancara yang peneliti lakukan dengan Sekretaris Badan Penanggulangan Bencana Daerah (BPBD) Kabupaten Sintang pada tanggal 30 Mei 2017, diungkapkan bahwa Kabupaten Sintang merupakan daerah yang berpotensi rawan bencana. Bencana alam yang sering terjadi di Kabupaten Sintang adalah banjir, kekeringan, kebakaran hutan (kabut asap) dan longsor. Lebih lanjut diungkapkan bahwa, terdapat beberapa kecamatan yang rawan terjadi bencana, daerah-daerah tersebut antara lain adalah Kecamatan Dedai, Sintang, Tempunak, Sepauk, Kayan Hulu, Kayan Hilir, Ketungau Hulu, Ketungau Hilir dan Ketungau Tengah. Karena itu, apabila bencana alam terjadi tentu akan membawa dampak bagi lingkungan sekitarnya dan akan mempengaruhi setiap aktivitas manusia.

Menyikapi bencana kabut asap yang pernah terjadi akibat kebakaran hutan maka Dinas Pendidikan Kabupaten Sintang mengambil kebijakan untuk meliburkan sekolah untuk beberapa waktu. Hal ini secara tidak langsung mengganggu 
proses belajar mengajar, sehingga akan berdampak juga pada hasil belajar siswa pada akhirnya. Hasil belajar merupakan poin penting dalam pembelajaran, sebagai ukuran untuk melihat keberhasilan dari proses pembelajaran yang telah dilaksanakan.

Berdasarkan permasalahan tersebut di atas maka dianggap penting untuk menerapkan model pembelajaran inovatif yang cocok dengan permasalahan yang dihadapi peserta didik yang berada pada daerah bencana kabupaten Sintang. Model pembelajaran tersebut adalah model pembelajaran IPA mitigasi bencana. Agustiana dkk., (2013: 102), mengungkapkan bahwa "Model pembelajaran mitigasi bencana berfokus pada konsep-konsep dan prinsip-prinsip utama dari suatu disiplin, melibatkan siswa dalam kegiatan pemecahan masalah dan tugas-tugas bermakna lainnya, dan memberi peluang siswa untuk memitigasi bencana secara dini". Model pembelajaran IPA mitigasi bencana merupakan model pembelajaran IPA yang dirancang dengan menyajikan materi konsep IPA dasar yang dipadukan atau diintegrasikan dengan konsep kebencanaan alam. Bencana alam tersebut adalah bencana yang dekat dengan kehidupan pada siswa sehari-hari, siswa harus memiliki wawasan mengenai mitigasi bencana. Dengan memberikan kesempatan bagi peserta didik untuk belajar secara individu maupun berkelompok untuk mengembangkan kemampuannya.

Tujuan umum penelitian ini yaitu; mengetahui efektivitas model pembelajaran IPA mitigasi bencana terhadap hasil belajar siswa kelas IV SD Negeri 09 Sintang. Sedangkan rumusan masalah khusus dalam penelitian ini yaitu; (a) mengetahui proses pembelajaran di kelas eksperimen dengan penggunaan model pembelajaran IPA mitigasi bencana; (b) mengetahui proses pembelajaran di kelas kontrol; (c) mengetahui peningkatan hasil belajar siswa sebelum dan sesudah menggunakan model pembelajaran IPA mitigasi bencana; (d) mengetahui peningkatan hasil belajar siswa sebelum dan sesudah menggunakan model pembelajaran IPA mitigasi bencana; (e) mengetahui perbedaan yang signifikan hasil belajar siswa pretest pada kelas eksperimen dan kelas kontrol; (f) Mengetahui perbedaan yang signifikan hasil belajar siswa posttest pada kelas eksperimen dan kelas kontrol (g) Mengetahui efektivitas penggunaan model pembelajaran IPA mitigasi bencana; (h) Mengetahui respon siswa terhadap penggunaan model pembelajaran IPA mitigasi bencana pada materi perubahan kenampakan bumi di kelas eksperimen.

\section{Metode Penelitian}

Metode penelitian yang digunakan dalam penelitian ini adalah metode penelitian eksperimen dengan pendekatan kuantitatif. Bentuk penelitian yang digunakan adalah quasi experimental designdengan menggunakan nonequivalent control group design.

Populasi dalam penelitian ini adalah seluruh siswa kelas IV SD Negeri 09 Sintang sebanyak 49 siswa. Teknik pengambilan sampel yang digunakan adalah nonprobability samplingdengan cara sampling jenuh artinya seluruh populasi digunakan sebagai sampel, siswa kelas IV A yang berjumlah
24 siswa sebagai kelas eksperimen dan siswa kelas B berjumlah 25 siswa sebagai kelas kontrol.

Pelaksanaan pembelajaran dilaksanakan sebanyak dua kali pertemuan. Pengumpulan data menggunakan beberapa instrumen yaitu: (a) lembar observasi digunakan untuk melihat proses pembelajaran di kelas eksperimendengan penggunaan model pembelajaran IPA mitigasi bencana dan kelas kontrol dengan penggunaaan model pembelajaran konvensional, (b) Lembar pengukuran menggunakan soal tes, lembar penilaian afektif dan lembar penilaian psikomotorik. Soal tes digunakan untuk melihat hasil belajar siswa dari aspek kognitif siswa, lembar penilaian afektif digunakan untuk mengukur sikap ilmiah siswa saat mengikuti setiap pembelajaran yang dilaksanakan, lembar penilaian psikomotorik digunakan untuk melihat dan mengukur kemampuan psikomotorik siswa yang berkaitan dengan keterampilan siswa pada saat proses pembelajaran berlangsung, (c) angket digunakan untuk melihat respon siswa terhadap penggunaan model pembelajaran IPA mitigasi bencana pada pembelajaran pada materi perubahan kenampakan pada bumi di kelas eksperimen, (d) dokumentasi sebagai bukti pelaksanaan penelitian. Analisis data yang dilakukan pada nilai tes meliputi (a) Uji normalitas menggunakan rumus chi kuadrat, (b) uji homogenitas dengan menggunakan rumusuji $\mathrm{F}$, (c) uji hipotesis menggunakan rumus uji t dua sampel, (d) uji efektivitas

\section{HASIL DAN PEMBAHASAN}

Berdasarkan hasil analisis lembar observasi guru dikelas eksperimen dengan model pembelajaran IPA mitigasi pada pertemuan pertama dan pertemuan kedua menunjukan angka $100 \%$.Berdasarkan persentase tersebutmenunjukkankesiapan dari peneliti dalam implementasi model pembelajaran IPA mitigasi bencana dalam pembelajaran. Artinya guru telah menerapkan rencana pelaksanaan pembelajaran secara keseluruhan, sehingga pembelajaran berkategori baik. Sedangkan rata-rata persentase hasil observasi siswa pertemuan pertama dan pertemuan kedua setelah dihitung menunjukkan angka 97,77\%. Persentase tersebut menunjukkan bahwa sebagian besar siswa sudah mengikuti pembelajaran dengan aktif, fokus dan konsentrasi, ketika ditanya oleh guru siswa memiliki kepercayaan untuk menjawab pertanyaan dengan baik.

Observasi di kelas kontrol dilakukan pada saat berlangsungnya pembelajaran dalam proses pembelajaran pada materi perubahan kenampakan pada bumi. Rata-rata persentase hasil observasi guru pertemuan pertama dan pertemuan kedua setelah dihitung menunjukkan angka 100\%. Artinya guru telah melaksanakan pembelajaran mulai dari pendahuluan sampai penutup pembelajaran dengan sangat baik yaitu sesuai dengan rangkaian kegiatan pembelajaran yang terdapat pada rencana pelaksanaan pembelajaran. Sedangkan rata-rata persentase hasil observasi siswa pertemuan pertama dan pertemuan kedua menunjukkan angka 92\%. Dari Hasil persentase tersebut artinya masih terdapat siswa yang belum sepenuhnya mengikuti pembelajaran 
dengan baik terbukti masih ada siswa yang belum aktif, ribut dan asik bercerita dengan temannya saat proses pembelajaran berlangsung.

Sebelum sampel penelitian diberikan perlakuan, terlebih dahulu dberikan pretest kepada kelas IV A selaku kelas eksperimen dan kelas IV selaku kelas kontrol. Nilai kemampuan awal siswa pada pretestkelas eksperimen dan kelas kontrol dapat dilihat pada Tabel 1.

Tabel 1. Nilai Pretest dan Posttest Siswa

\begin{tabular}{|c|c|c|c|c|c|}
\hline \multirow[b]{2}{*}{ Kelas } & \multirow{2}{*}{$\begin{array}{c}\text { Jumlah } \\
\text { Siswa }\end{array}$} & \multicolumn{2}{|c|}{ Nilai } & \multirow{2}{*}{$\begin{array}{l}\text { Nilai } \\
\text { Rata- } \\
\text { Rata }\end{array}$} & \multirow[b]{2}{*}{ Kategori } \\
\hline & & Terendah & Tertinggi & & \\
\hline \multicolumn{6}{|c|}{ Pretest } \\
\hline Eksperimen & 24 & 11 & 64 & 36,75 & Rendah \\
\hline Kontrol & 25 & 20 & 61 & 38,4 & Rendah \\
\hline \multicolumn{6}{|c|}{ Posttest } \\
\hline Eksperimen & 24 & 64 & 98 & 80,75 & Tinggi \\
\hline Kontrol & 25 & 60 & 87 & 70,6 & Sedang \\
\hline
\end{tabular}

Nilai kemampuan akhir siswa pada posttest setelah digabungkan pada ketiga aspek, aspek kognitif, afektif dan psikomotorik kelas eksperimen dan kelas kontrol. Perhitungan rata-rata pretest pada tes awal diperoleh sebesar 36,75. Sedangkan rata-rata posttest pada tes akhir diperoleh sebesar 80,75 dimana terdapat $83,33 \%$ siswa yang memenuhi kriteria ketuntasan minimal dan $16,66 \%$ siswa tidak memenuhi kriteria ketuntasan minimal. Hasil belajar dari pretest dan posttest pada kelas eksperimen mengalami peningkatan sebesar 0,69. Sedangkan pada kelas kontrol perhitungan ratarata pretest pada test awal diperoleh sebesar 38,4. Analisis hasil pretest menunjukan bahwa tidak terdapat siswa yang memenuhi kriteria ketuntasan minimal. Sedangkan pada perhitungan rata-rata posttest pada hasil belajar untuk kelas kontrol diperoleh 70,6 dimana terdapat 44\% siswa yang memenuhi kriteria ketuntasan minimal dan terdapat 56\% siswa tidak memenuhi kriteria ketuntasan minimal. Hasil belajar dari pretest dan posttest pada kelas eksperimen mengalami peningkatan sebesar 0,52.

Efektivitas model pembelajaran IPA mitigasi bencana dihitung menggunakan effect size, skor perhitungan dilihat dari perolehan di kelas eksperimen dan kelas kontrol. Efektivitas merupakan suatu ukuran yang dipakai untuk melihat sejauh mana suatu rencana dapat tercapai. Data hasil perhitungan dapat dilihat pada tabel 2 .

Tabel 2. Efektivitas Model Pembelajaran IPA Mitigasi

\begin{tabular}{|c|c|c|c|c|c|}
\hline \multicolumn{3}{|c|}{ Bencana } & & & \\
\hline No & Jenis Tes & $\begin{array}{c}\text { SD } \\
\text { Kontrol }\end{array}$ & Kelas & $\begin{array}{l}\text { Hasil } \\
\text { Hitung }\end{array}$ & Ket. \\
\hline 1 & $\begin{array}{l}\text { Posttest } \\
\text { Eksperimen }\end{array}$ & 80,75 & \multirow{2}{*}{8,72} & \multirow{2}{*}{1,16} & \multirow{2}{*}{$\begin{array}{l}\text { Efektivitas } \\
\text { Tinggi }\end{array}$} \\
\hline 2 & $\begin{array}{c}\text { Posttest } \\
\text { Kontrol }\end{array}$ & 70,6 & & & \\
\hline
\end{tabular}

Selanjutnya dilakukan uji hipotesis pada pretest dan posttestkelas eksperimen dan kelas kontrol yang bertujuan menjawab rumusan masalah yaitu apakah terdapat perbedaan yang signifikan hasil belajar siswa pada materi perubahan kenampakan pada bumi. Uji hipotesis dilakukan dengan uji $\mathrm{t}$ dua sampel. Sebelum dilakukan pengujian hipotesis dilakukan terlebih dahulu uji prasyarat yaitu normalitas dan homogenitas.Hasil perhitungan normalitas dapat dilihat pada tabel 3, sedangkan hasil perhitungan homogenitas dapat dilihat pada tabel 4 dan tabel 5 .

Tabel 3. Uji Normalitas Hasil Belajar

\begin{tabular}{cccccc}
\hline $\begin{array}{c}\text { Data yang } \\
\text { dikaji }\end{array}$ & $\bar{X}$ & SD & $X_{\text {Hitung }}^{2}$ & $X_{\text {Tabel }}^{2}$ & Ket. \\
\hline $\begin{array}{c}\text { Pretest } \\
\text { Eksperimen }\end{array}$ & 36,75 & 13,24 & 4,73 & 7,815 & Normal \\
\hline $\begin{array}{c}\text { Pretest } \\
\text { Kontrol }\end{array}$ & 38,4 & 10,10 & 1,81 & 7,815 & Normal \\
\hline $\begin{array}{c}\text { Posttest } \\
\text { Ekperimen }\end{array}$ & 80,75 & 9,49 & 4,69 & 7,815 & Normal \\
\hline $\begin{array}{c}\text { Posttest } \\
\text { Kontrol }\end{array}$ & 70,6 & 8,72 & 3,25 & 7,815 & Normal \\
\hline
\end{tabular}

Berdasarkan hasil perhitungan statistik untuk hasil belajar siswa menunjukan bahwa taraf kepercayaan $\alpha=5 \%(0,05), \mathrm{X}^{2}$ hitung $\left\langle X^{2}\right.$ tabel yaitu data pretestkelas IV A sebagai kelas eksperimen 4,73<7,815, pretestkelas IV B sebagai kelas kontrol 1,81<7,815, posttest kelas IV A sebagai kelas eksperimen 4,69 $<7,815$, posttestkelas IV B sebagai kelas kontrol 3,25 < 7,815. Dengan demikian maka dapat dinyatakan bahwa sebaran data kelas IV A dan IV B dalam penelitian ini berdistribusi normal.

Tabel 4. Hasil Uji Homogenitas Prestest Hasil Belajar

\begin{tabular}{cccccc}
\hline No & $\begin{array}{c}\text { Data yang } \\
\text { Diuji }\end{array}$ & SD & $\mathrm{F}_{\text {hitung }}$ & $\mathrm{F}_{\text {tabal }}$ & Ket \\
\cline { 1 - 3 } 1 & $\begin{array}{c}\text { Pretest } \\
\text { Eksperimen }\end{array}$ & 13,24 & 1,71 & 1,99 & Homogen \\
\cline { 1 - 3 } 2 & $\begin{array}{c}\text { Pretest } \\
\text { Kontrol }\end{array}$ & 10,10 & & & \\
\hline
\end{tabular}

Hasil perhitungan menunjukan bahwa F_hitung < F_(tabel,) yaitu pretest kelas eksperimen dan kelas kontrol sebesar 1,71 $<1,99$. Maka dapat dinyatakan bahwa data pretesthasil belajar kelas eksperimen dan kelas kontrol dalam penelitian ini adalah homogen.

Tabel 5. Hasil Uji Homogenitas Posttest Hasil Belajar

\begin{tabular}{cccccc}
\hline No & $\begin{array}{c}\text { Data yang } \\
\text { Diuji }\end{array}$ & SD & $\mathrm{F}_{\text {hitung }}$ & $\mathrm{F}_{\text {tabel }}$ & Ket \\
\cline { 1 - 3 } 1 & $\begin{array}{c}\text { Posttest } \\
\text { Eksperimen }\end{array}$ & 9,49 & & 1,99 & Homogen \\
\cline { 1 - 3 } 2 & $\begin{array}{c}\text { Posttest } \\
\text { Kontrol }\end{array}$ & 8,72 & 1,18 & & \\
\hline
\end{tabular}

Hasil perhitungan menunjukan bahwa F_hitung < F_(tabel, ) yaitu posttest kelas eksperimen dan kelas kontrol sebesar 1,18 $<1,99$. Maka dapat dinyatakan bahwa data posttest hasil belajar kelas eksperimen dan kelas kontrol dalam penelitian ini adalah homogen.Karna kedua data berdistribusi normal dan homogen maka selanjutnya dilakukan uji parametrik. Hasil uji t dua sampel pretestkelas eksperimen dan kelas kontrol dapat dilihat pada tabel 6 . 
Tabel 6. Hasil Uji Hipotesis dengan Uji t Dua Sampel Pretest Hasil Belajar Kelas Eksperimen dan Kelas Kontrol

\begin{tabular}{cccccl}
\hline Kelas & $\mathrm{N}$ & $\begin{array}{c}\text { Rerata } \\
\text { Pretest }\end{array}$ & $\begin{array}{c}t_{\text {tabal }} \\
(\alpha-5 \%) \\
\mathrm{db}=47\end{array}$ & $t_{\text {hitung }}$ & Keterangan \\
\hline Eksperimen & 24 & 36,75 & & & $\begin{array}{l}\text { Tidak } \\
\text { terdapat } \\
\text { perbedaan }\end{array}$ \\
\cline { 1 - 2 } Kontrol & 25 & 38,4 & 2,02835 & $-0,495$ & $\begin{array}{l}\text { yang } \\
\text { signifikan }\end{array}$ \\
\hline
\end{tabular}

Hasil perhitungan menunjukkan bahwa t_hitung adalah 0,495 sedangkant_tabel adalah 2,02835, maka Ha ditolak dan Ho diterima. Artinya tidak terdapat perbedaan yang signifikan hasil belajar siswa antara kelas eksperimen dan kelas kontrol. Hasil uji t dua sampel posttest kelas eksperimen dan kelas kontrol dapat dilihat pada tabel 7.

Tabel 7 Hasil Uji Hipotesis dengan Uji t dua Sampel Posttest Hasil Belajar Kelas Eksperimen dan Kontrol

\begin{tabular}{|c|c|c|c|c|c|}
\hline Kelas & $\mathrm{N}$ & $\begin{array}{c}\text { Rerata } \\
\text { Posttest }\end{array}$ & $\begin{array}{c}t_{\text {tabel }} \\
(\alpha-5 \%) \\
\mathrm{db}=47\end{array}$ & $t_{\text {hitung }}$ & Keterangan \\
\hline IV A & 24 & 80,75 & \multirow[b]{2}{*}{2,02835} & \multirow[b]{2}{*}{3,94} & $\begin{array}{l}\text { Terdapat } \\
\text { perbedaan } \\
\text { yang } \\
\text { signifikan } \\
\text { hasil } \\
\text { belajar }\end{array}$ \\
\hline IV B & 25 & 70,6 & & & $\begin{array}{l}\text { siswa pada } \\
\text { kelas } \\
\text { eksperimen } \\
\text { dan siswa } \\
\text { pada kelas } \\
\text { kontrol. }\end{array}$ \\
\hline
\end{tabular}

Berdasarkan hasil perhitungan diketahui bahwa nilai t_hitung adalah 3,94 sedangkan t_tabel pada $a=5 \%$ adalah 2,02835. Hal ini berarti nilai t_hitung $\geqslant t$ ttabel yaitu 3,06 $\geqslant 2,02825$ maka Ha diterima dan Ho ditolak, artinya terdapat perbedaan yang signifikan hasil belajar siswa dengan model pembelajaran IPA mitigasi bencana pada kelas eksperimen dan siswa pada kelas kontrol dengan pembelajaran konvensional pada pengukuran posttest. Dengan demikian dapat disimpulkan bahwa terdapat perbedaan secara signifikan hasil belajar siswa kelas eksperimen dan kelas kontrol. Hal ini sejalan dengan keberhasilan penggunaaan model pembelajaran mitigasi bencana oleh Agustina dkk., (2013: 101) yang menyatakan bahwa, "Berdasarkan hasil perhitungan dalam penelitian ini menunjukan pemahaman siswa pada mata pelajaran IPA antara siswa yang diajar dengan model pembelajaran mitigasi bencana secara signifikan lebih tinggi dibandingkan dengan siswa yang diajar dengan model pembelajaran konvensional". Demikian pula dengan penelitian yang dilakukan oleh Wedyawati, N. (2017) menunjukkan hasil terdapat perbedaan yang signifikan hasil belajar siswa kelas eksperimen dan kontrol setelah pembelajaran.

Untuk melihat respon siswa terhadap pembelajaran yang telah dilakukan peneliti menyebarkan angket respon siswa setelah posttest. Pemberian angket respon siswa ini bertujuan untuk mengetahui tanggapan atau respon siswa setelah belajar menggunakan model pembelajaran IPA mitigasi bencana. Hasil angket respon siswa dapat dilihat pada tabel 8 .

Tabel 8. Hasil Angket Respon Siswa Terhadap Model Pembelajaran IPA Mitigasi Bencana

\begin{tabular}{cc}
\hline \multicolumn{2}{c}{ Hasil Angket } \\
\hline$\%$ & 97,91 \\
\hline Kategori & Sangat Kuat \\
\hline
\end{tabular}

Secara keseluruhan respon siswa kriteria sangat kuat. Hal ini membuktikan bahwa siswa merasa senang dan bersemangat dalam belajar, siswa berani berpendapat, siswa aktif dan antusias dalam mengikuti pembelajaran serta siswa mampu bekerja sama dengan teman kelompok sehingga tampak suasana kelas yang lebih kondusif dan menyenangkan. Dari hasil rata-rata persentase respon siswa dapat disimpulkan bahwa adanya respon positif dari siswa mengenaipenerapan model pembelajaran IPA mitigasi bencana pada proses pembelajaran dilaksanakan dengan materi perubahan kenampakan pada bumi. Penelitian Wedyawati, N (2014) menyimpulkan pembelajaran kebencanaan bervisi SETS dapat diajarkan dengan berbagai model pembelajaran. model pembelajaran IPA berbasis mitigasi bencana sangat baik diterapkan pada siswa sekolah dasar terutama pada siswa yang bersekolah pada daerah rawan bencana. Penerapan model ini dapat membantu siswa memahami apa saja yang harus dilakukan pra bencana, saat bencana, dan pasca bencana. Siswa tidak hanya memahami apa yang diberikan tetapi siswa juga dapat dijadikan sebagai informan kepada masyarakat sekitar.

\section{KESIMPULAN DAN SARAN}

Kesimpulan yang diperoleh dalam penelitian ini yaitu: (a) proses pembelajaran guru dan siswa pada kelas eksperimen untuk observasi guru diperoleh persentase $100 \%$ sedangkan untuk persentase aktivitas siswa pertemuan pertama dan pertemuan kedua dengan rata-rata 97,77\% berkriteria baik; (b) proses pembelajaran guru dan siswa pada kelas kontrol untuk observasi guru diperoleh persentase $100 \%$ sedangkan untuk aktivitas siswa pertemuan dan pertemuan kedua dengan ratarata $92 \%$ berkriteria baik.; (c) peningkatan hasil belajar kelas eksperimen sebesar 0,69 dengan kategori tinggi. Perolehan persentase hasil belajar pada pretest sebesar 36,75 dengan kategori rendah sedangkan persentase hasil belajar posttest sebesar 80,75 dengan kategori tinggi; (d) peningkatan hasil belajar kelas kontrol sebesar 0,52 dengan kategori sedang. Perolehan persentase hasil belajar pada pretest sebesar 38,4 
dengan kategori rendah sedangkan persentase hasil belajar posttest sebesar 70,6 dengan kategori sedang; (e) hasil perhitungan effect size sebesar 1,16 dengan kategori tinggi; (f) tidak terdapat perbedaan yang signifikan hasil belajar pretest siswa pada kelas eksperimen dan kelas kontrol. Dengan hasil perhitungan sebesar $-0,495<-2,02835$, artinya Ho di terima dan Ha ditolak; (g) terdapat perbedaan yang signifikan hasil belajar posttest siswa pada kelas eksperimen dan kelas kontrol. Dengan hasil perhitungan sebesar 3,94 $\geqslant 2,02835$, artinya Ho ditolak dan Ho diterima; (h) respon siswa setelah proses pembelajaran dengan model pembelajaran IPA mitigasi bencana sebesar 97,91\% dengan kategori sangat kuat (positif).

Saran dari penelitian ini bagi peneliti selanjutnya, diharapkan dapat memilih model pembelajaran yang akan diterapkan kepada siswa dengan menyesuaikan materi pelajaran, dan menyesuaikan dengan hal-hal yang menjadi prioritas atau yang dibutuhkan siswa. Sehingga tujuan pembelajaran tercapai dan memberikan pengetahuan baru bagi siswa.

\section{DAFTar Pustaka}

Agustina, I. G.A.T., Wibawa, I.M. C., Tika, I.N. 2013. Pengaruh Model Pembelajaran Mitigasi Bencana Terhadap Pemahaman dan Ketahan-Malangan Siswa. Jurnal Pendidikan dan Pengajaran. Jilid 46, No. 2, Juli 98 Halaman 97-105.

K, Chandra. R., Dan Supriharjo, R. D. 2013. Mitigasi Bencana Banjir Rob di Jakarta Utara. Jurnal Teknik Pomits. Volume 2 No. 1, ISSN: 23373539.

Sugiantari. Suarni., Dan Margunayasa. 2013. Pengaruh Model Pembelajaran Kontekstual Terhadap Hasil Belajar IPA Kelas V SDN di Kelurahan Kaliuntu. Articles MIMBAR PGSD. Volume 1.

Wedyawati, N. 2014. Pembelajaran IPA bervisi SETS untuk peningkatan Prestasi belajar dan peningkatan sikap tanggap Bencana siswa kelas IV SD Swasta \& Negeri Nanga Pinoh. Jurnal VOX Education. Volume 5 nomor 2 hal. 43-50.

Wedyawati, N., Lisa, Y., dan Selimayati, S. 2017. Pengaruh Model Pembelajaran IPA Terintegrasi Mitigasi Bencana Terhadap Hasil Belajar.Jurnal Edukasi. Vol 15 Nomor 2 hal. 261-273.

Wedyawati, N., Dan Lisa, Y. 2017. Ilmu Pengetahuan Alam (IPA) Terintegrasi Mitigasi Bencana Untuk SD/MI Kelas IV. Sintang: STKIP Persada Khatulistiwa.

Wedyawati, N., Dan Lisa, Y. 2017. Developing Integrated Natural Sciences Disaster Mitigation Model For Elementary School Sintang. Jurnal of Education Science and Technology (EST). Volume 3 No 2, p-ISSN: 2477-3840 dan eISSN: 2477-3840. 